\title{
AGRO-INDUSTRIAL WASTE WITH POTENTIAL USE AS A SUBSTRATE IN THE PRODUCTION OF BIOSURFACTANT.
}

\author{
Márcio Costa Pinto da Silvaa; Edna dos Santos Almeidab; Érika Durão Vieirac; Bruna Pita ${ }^{\mathrm{d}}$ \\ a SENAI CIMATEC, Brazil, Bioprocess Depart.; marcio.silva@doc.senaicimatec.edu.br \\ b SENAI CIMATEC, Brazil, Bioprocess Depart.; ednasa@fieb.org.br \\ c SENAI CIMATEC, Brazil, Bioprocess Depart.; erika@fieb.org.br \\ dSENAI CIMATEC, Brazil, Bioprocess Depart.; brunalmpita@gmail.com
}

\begin{abstract}
The aim of this work is a technical economic comparison limited to five agro-industrial waste as a possible substrate for biosurfactants production. The wastes selected were: sugarcane bagasse, sugarcane molasses, manipueira, residual frying oil and oily sludge. The primary comparative data collected in the literature were: availability in the market with low or no commercial value; needs of treatments for use as substrate and availability of carbon source. Of the residues, the best comparative performance in these 3 factors was oily sludge: it has availability and no market value, simple reproduction treatment for adaptation as a substrate and a great carbon source.
\end{abstract}

Keywords: agro-industrial waste; substrate; comparation; oily sludge; biosurfactant.

\section{RESÍDUOS AGRO-INDUSTRIAIS COM POTENCIAL UTILIZAÇÃO COMO SUBSTRATO NA PRODUÇÃO DE BIOSURFACTANTES.}

Resumo: Este artigo faz uma comparação técnico econômica limitado a cinco resíduos agro-industrais como fonte possível de substrato para produção de biossurfactantes. Os resíduos selecionados foram: bagaço de cana-de-açúcar, melaço de cana-de-açúcar, manipueira, óleo residual de fritura e borra oleosa. Os principais dados comparativos coletados na bibliografia foram: disponibilidade no mercado com baixo ou nenhum valor comercial; tratamentos necessários para uso como substrato e disponibilidade de fonte de carbono. Dos resíduos o de melhor desempenho comparativo nestes 3 fatores foi a borra oleosa: tem disponibilidade $e$ sem valor de mercado, tratamento de simples reprodução para adaptação como substrato e boa fonte de carbono.

Palavras-chave: resíduo agroindustrial; substrato; comparação; borra oleosa; biossurfactante. 


\section{INTRODUCTION}

Biosurfactants are substances synthesized by microorganisms and have ability to reduce surface tensions, having low toxicity, high biodegradability, with production from renewable sources [1]. However, the production of biosurfactants is limited by the high cost, due to low productivity and use of expensive substrates. The metabolites produced from cheap, renewable substrates and through economically viable processes allow to reduce the production costs of biosurfactants [1].

The use of an agro-industrial waste for the use of low cost substrate for the production of biosurfactant will depend on its wide availability, at low or no cost and which has a good availability of carbon source. Many agro-industrial wastes are available in nature. However, some agro-industrial already developed their chain of use, raising their price for use as a substrate as well as other technical limitations.

Another important decision for this choice is the type of fermentation. Many substrates lead to liquid fermentation (LF), while others substrates, such as sugar cane bagasse, needs semi-solid fermentation (SSF). In liquid fermentation (LF) the components are diluted and the contact are facilitates, homogeneity and ease of agitation. In semi-solid fermentation (SSF), the cellulose content, that contains the carbon source, is not easily available to be used in fermentation and for that it needs pretreatments of this substrates. This generally causes an increase in the cost of the process [2]. At this point, the operation of liquid fermentation is simpler than semi-solid fermentation [3].

\section{METHODOLOGY}

Through bibliographic references, comparative data were collected, such as: origin, uses and main analyzes for use as a substrate limited to the following agroindustrial wastes: sugarcane bagasse; cane molasses; liquid extracted by the cassava pressing, (manipueira); residual frying oil and oily sludge mixture.

\subsection{Sugarcane bagasse (SB)}

For the use of sugarcane bagasse (SB) in a fermentation process, it is necessary to do some initial treatments. The first step is drying to reduce the average humidity from $50 \%$ to below $5 \%$, circulating air at $60{ }^{\circ} \mathrm{C}$ for 72 hours. Then, the bagasse is processed in a knife mill and sieved until it passes through sieves with 1.1 and $2.5 \mathrm{~mm}$ meshes, where granulometric separations are made [4]. Ending this step with a prewash and filtering to remove soil residues, ash and mainly residual sugar and other water-soluble low molar glycids [5].

Before semi-solid fermentation it is necessary to carry out the grinding steps of this residue to increase the contact surface and pre-treatments for the cellulose release and hydrolysis, making the fermentation step more expensive. 
The presence of hemicellulose and lignin, forms a structure that surrounds the sugarcane bagasse cellulose chains, making it difficult for reagents and catalysts to access, requiring a pre-treatment to remove these components to access of cellulose enzymes [6].

To release the cellulose inserted in the recalcitrant fibers of the sugarcane bagasse, a pretreatment is necessary, which can be acidic or with steam. In acid pre-treatment, sulfuric acid $\left(\mathrm{H}_{2} \mathrm{SO}_{4}\right)$ at 7.0 and $9.0 \%$ is used, under the following conditions: 1 atmosphere and $121^{\circ} \mathrm{C}$. In the steam pre-treatment, called a steam explosion, there is both chemical and physical action on the structure of the lignocellulosic material, because it is based on the direct contact of the biomass with saturated steam at high pressure for a certain exposure time in the reactor, followed by rapid decompression to atmospheric condition (explosion). Throughout this process, the bonds of lignin and hemicellulose, which ensure the cohesion of the biomass, are weakened and partly broken, so that, at the time of decompression, the material is easily defibrated and thus reduced to smaller particles, increasing the surface area of contact and decreasing the resistance of the cell wall to saccharification [6].

Generally in the steam explosion the biomass is heated for a few minutes through contact with saturated steam with pressure between 0,69 to $4,83 \mathrm{MPa}$ and temperature between 169 to $260{ }^{\circ} \mathrm{C}$ [7], making the steam penetrates the material. This pressurized system subsequently undergoes a sudden decompression, breaking the fibers structure of biomass [8].

It is important to highlight that sugarcane bagasse, despite being an agroindustrial waste with the potential to serve as a substrate, in addition to the limitation stated above, this waste currently has a very specific use in alcohol and sugar mills, being used in boilers for burning and consequent generation of steam and electric energy [6]. In this case it is a waste that already has a specific purpose and a make value. In this way, it makes it unfeasible or uses is as a low-cost substrate for the production of bio-surfactant.

\subsection{Sugar Cane Molasses}

Sugar cane molasses is a syrup produced from the evaporation of sugarcane broth or during the production of rapadura, and has a strong sweetening power.

The sugarcane molasses requires pretreatment as sugarcane bagasse. The most suitable pretreatment for clarifying sugarcane molasse is carried out with $8 \%$ active carbon for 1 hour under stirring at $90^{\circ} \mathrm{C}$, followed by centrifugations, filtration in 0.08 to $0.02 \mathrm{~mm}$ cellulose acetate membrane. Then, the sugarcane molasse solution with charcoal is cooled and vacuum filtered. Finally to completely remove coal residues for membrane ultrafiltration method [9].

The analyzes that are made for use as substrate are: total reducing sugars, soluble solids, ${ }^{\circ}$ brix and sulfated ash.

Sugarcane molasses has high commercial value and specific use. This is a natural sweetener that can be used to replace sugar, bringing more benefits, 
especially because it contains more nutrients like magnesium and iron. Also used in agriculture as a powerful and natural fertilizer. The sugarcane molasse is the product with a source of several chemical elements essential for soil fertility, such as calcium, phosphorus, potassium, magnesium and proteins.

\subsection{Manipueira}

Manipueira is the liquid extracted from the cassava when it is pressed in the flour manufacturing process. Both cassava and this liquid contain hydrocyanic acid, poisonous and harmful to human and animal food [10].

To remove the poison from the manipueira to be used as a safe food supplement, it is necessary to subject it to anaerobic fermentation, that is, let the liquid rest for 15 days in a fenced tank. The hydrocyanic acid, which is considered poisonous, evaporates and the manipueira remains ready to serve as a food supplement for cattle.

The manipueira contains a good source of carbon through sugars. Reducing sugars are determined by the Fehling method. Non-reducing agents are hydrolyzed and determined as total reducing sugars. The difference obtained between reducing sugars after hydrolysis and the amount of reducing sugars calculated previously (without hydrolysis) is expressed in non-reducing sugars [1]. Other analyzes made of manipueira for use as a substrate are: total solids, nitrogen, $\mathrm{pH}$ and ash.

Manipueira is a great food supplement for cattle. The manipueira also serves to fight pests and diseases, control ants and insects and even manufacture vinegar and soap. Mixed with castor oil, it can also be used to control ticks. As an organic fertilizer, the dilution of the manipueira depends on the crop and the form to be applied, which can be in the soil or in the foliage [10].

\subsection{Residual frying oil}

Vegetable oils are natural products formed mainly by triglycerides and are used mainly in cooking and in the production of biofuel. Currently, there is a great use of vegetable oils in frying food by immersion, consequently generating a large volume of residual oil. Brazil produces approximately four billion liters of frying oil per year [11]. Residual frying oil can be used to produce different compounds, such as soap, glue, paint and biodiesel [12]. However, in the frying process, the thermal and physical chemical properties of vegetable oil are altered, affecting the loss of polyunsaturated fatty acids. These fatty acids are the necessary carbon source for fermentation to produce biosurfactants [13].

The following analyzes are made to characterize this substrate: free fatty acid, moisture, volatiles and ashes or saponifiable.

The gas chromatography analysis aims to verify the profile of pure individual fatty acids (usually in the form of methyl esters). The composition of fatty acids is determined from the extraction of methyl esters, which helps in the assessment of 
the nutritional content of oils and fats. Through this method the fatty acid methyl esters are separated, identified and quantified by gas chromatography. This quantification of methyl esters of fatty acid is indicated for fatty acids that contain between 4 to 24 carbon atoms [13].

\subsection{Oil sludge}

The sludge from the mixture of cotton and soy oil, in the proportion of $1: 1$, by mass is originated in the blender refining process of these two oils. Refining consists of heating the crude oil from room temperature to $50{ }^{\circ} \mathrm{C}$, in a tube-hull type heat exchanger. After heating, a mixture is made with the diluted caustic soda, in a previously prepared concentration, which varies between 10 to $20 \%$, depending on the acidity of the oil. The heated crude oil and the caustic soda are mixed in a line mixer and proceed to the contact tower where the neutralization reaction of free fatty acids occurs. After this contact tower, the neutralized oil and the residues are heated to $75^{\circ} \mathrm{C}$ and proceed to the centrifuge. The sludge leaves the top of the centrifuge at a temperature of $70{ }^{\circ} \mathrm{C}$, with a color ranging from light brown to dark brown, depending on the initial acidity of the crude oil, which varies between $1.0 \%$ to $3.0 \%$ [14]. This sludge contains: triglycerides, saponifiable material, fatty acid salts, nonhydratable phosphatides, water and sodium salts [15] [16].

Refining generates about $8 \%$ sludge by mass. This sludge has no commercial value and there is still a cost for treatment before disposal. In the initial analyzes, it registers an average of total fatty acid, which is the carbon source of this sludge, of $39 \%$. It has a pasty form at room temperature, with an active odor and a dark color.

For the qualitative and quantitative physical-chemical analyzes of this sludge to obtain its characterization and the possibility of being used as a culture medium for bacteria for the production of biosurfactants, the following analyzes were made: determination of neutral oil; $\mathrm{pH}$; determination of the content of saponifiable residues; moisture and total fatty acid [17]. Since fatty acid is the most important component of the substrate, it is necessary to use gas chromatography to determine the amount and types of fatty acids. According to the methodology adapted from [18], the fatty acid esters were analyzed in a gas chromatograph with a mass spectrum detector. The carbon source present in the fatty acid is a value that makes oil sludge with good preference as a substrate.

\section{RESULTS AND DISCUSSION}

The economic viability of the production of biosurfactants at an industrial level is directly linked to the cost of the culture medium (substrate). In this sense, the use of low-cost or no industrial waste or by-products represents an excellent alternative for reducing costs in the production of biosurfactants, especially if this waste has a large carbon source, which is the main metabolite for the growth of microorganisms [19].

Among the other residues, with low or no cost, we highlight: manipueira, oily sludge and frying oil. Sugar cane bagasse and molasses have market value, and 
need for pre-treatment making the process more expensive, these two substrates being more expensive than the three mentioned.

For frying oil the composition is affected by the loss of polyunsaturated fatty acids. These fatty acids are the necessary carbon source for fermentation [13].

\section{CONCLUSION}

Thus, due to evidence of technical data on low or no cost substrates, the following stand out: the manipueira and oily sludge. The manipueira has a commercial use as a food supplement for livestock.

The conclusion is that oily sludge of soy origin or composed of soy and cotton is the best low-cost substrate, with no commercial value and with a good carbon source to produce biosurfactant.

\section{Acknowledgments}

To FAPESB, grant $0232 / 18$, for the financial support to the project.

\section{REFERENCES}

${ }^{1}$ BEZERRA, M. S. Estudo da Produção de biosurfactante sintetizados por Pseudomonas aeruginosa AP029-GVIIA utilizando manipueira como fonte de carbono, UFRN, 2012.

2 SANTOS, D et al. Potencialidades e Aplicações da Fermentação semi-sólida em biotecnologia. Universidade de Lorena, 2006.

\section{${ }^{3}$ AQUINO, PEDRO L. M. Produção de Biossurfactantes a partir de bacillus velezensis utilizando resíduos Agroindustriais como} substrato. Universidade Estadual Paulista,São José do Rio Preto, 2011.

${ }^{4}$ MORAIS, ALAINE P. S. Estudo do pré-tratamento do bagaço de cana-deaçúcar e caracterização físico-química. Dissertação (Mestrado)- Universidade Federal de Paulista, Faculdade de Ciências Agronômicas, Botucatu, São Paulo, 2010.

${ }^{5}$ PITARELO, A. P. Avaliação da susceptibilidade do bagaço e da palha da cana-de-açúcar à bioconversão via pré-tratamento à vapor e hidrólise enzimática. 2007, 142f. Dissertação (Mestrado). Curso de Química. Universidade Federal do Paraná. Curitiba, 2007. 
${ }^{6}$ SILVA, MÁRCIO C. P. Disponibilidade, pré-tratamento de matéria prima e projeto de reator a explosão à vapor para produção de E2G. Dissertação de Mestrado, UNIFACS, Salvador, 2015

${ }^{7}$ ZHENG, Y.; ZHAO, J..; XU, F.; LI, Y. Pretreatment of lignocellulosic biomass for enhanced biogas production. Progress in Energy and Combustion Science, Elsevier, Ohio, v.42, p.35-53, jun. 2014.

8 STELTE, W. Steam explosion for biomass pre-treatment. Centre for Renewable Energy and Transport. Section for Biomass - Danish Techonological Institute, Compenhague - Dinamarca, 2013.

${ }^{9}$ MARIM, MARÍLIA G Obtaining of biosurfactant by Bacillus subtilis ATCC 9372 from sugar cane molasses. $51 \mathrm{f}$. Trabalho de Conclusão de Curso de graduação em Engenharia de Alimentos. Universidade Tecnológica Federal do Paraná. Campo Mourão, 2014.

${ }^{10}$ EMBRAPA. Cartilha de publicação sobre a manipueira. Revista 2009.

${ }^{11}$ CARA, DIEGO V. C. Produção de Biossurfatante por Flavobacterium sp. a partir de óleo de soja residual e fertilizante comercial. Rio de Janeiro, 2009.

12 SILVEIRA, D. A.; VIEIRA, G. E. Emprego do óleo residual de fritura na produção de biodiesel vol. 1 num. 2 - XX Congresso Brasileiro de Engenharia Química, 2015.

${ }^{13}$ CARVALHO, ANDRESSA P. H. Qualidade física, química e antimicrobiana de sabões líquidos elaborados com óleo residual de fritura e diferentes agentes saponificantes. Dissertação de mestrado. Ciência e Tecnologia de Alimentos, Universidade Federal de Goiás, 2013.

${ }^{14}$ SILVA, MÁRCIO C. P. Preliminary evaluation use of lees generated in the refining vegetable oil mixture as a substrate for the production of biosurfactant. $5^{\text {th }}$ Latin American Congress on Biorefineries. Concepcion, Chile January, 2019.

${ }^{15} \mathrm{FRÉ}, \mathrm{N}$. C. Obtenção de ácidos graxos à partir da acidulação de borra de neutralização de óleo de soja. Dissertação de Mestrado, UFRS, 2009.

16 JUN, A. at al. Reatividade de Compostos Orgânicos II e Biomoléculas lipídios, ácidos graxos e fosfolipídeos. UNESP, São Paulo, 2016.

17 SANTOS, R. R. Caracterização e aplicação de borras do refino de óleos vegetais para produção de lipase fúngica por fermentação no estado sólido. Dissertação de Mestrado, UFFRJ, 2012.

${ }^{18}$ VOLKMANN, G. C. M.; JENSKE, G.; KREMER, L. C. Determinação de ácidos graxos em alimentos por cromatografia gasosa, 2014. 
19 NITSCHKE, MÁRCIA. et al. Oil Wastes as Unconventional Substrates for Rhamnolipid biosurfactant production by Pseudomonas aeruginosa LBI. Biotechnology Progress, n.5, p. 62-66, 2005 